\title{
A MINI REVIEW ON THE NUTRITIONAL COMPOSITIONS AND PHARMACOLOGICAL PROPERTIES OF Litsea garciae
}

\author{
ZUNIKA AMIT* and LING ZINYIN \\ Department of Basic Medical Sciences, Faculty of Medicine and Health Sciences, \\ Universiti Malaysia Sarawak, 94300 Kota Samarahan, Sarawak, Malaysia \\ *E-mail: zunika@unimas.my
}

Accepted 8 May 2021, Published online 30 June 2021

\begin{abstract}
Litsea garciae is an underutilized plant found in certain parts of South East Asia. The plant part has been traditionally used to treat, among others, skin infections, boil, rectal bleeding, muscular pain, and sprains. Besides its medicinal properties, its seasonal fruit is consumed for its avocado-like flavor. This article aims to provide information on what is known so far about the nutritional composition and pharmacological properties of Litsea garciae.
\end{abstract}

Key words: Antioxidant, Litsea garciae, pharmacological, phytochemical, underutilized fruit

\section{INTRODUCTION}

The Lauraceae or the laurel family contains 50 genera which include the genus Litsea. There are more than 400 species in the genus Litsea, and it is predominant in Asia, Australasia, and America (Sampson \& Berry, 2019) with 50 species can be found in Malaysia (Mehat, 2008; Poli \& Assim, 2019). The ethnopharmacological properties and medicinal uses of the genus Litsea have attracted much attention in researches (Wang \& Liu, 2010; Kamle et al., 2019). A few species of Litsea, for example, L. cubeba, L. japonica and L. salicifolia, have been extensively studied and are shown to be sources of secondary metabolites with important chemical structures including alkaloids, lactones, sesquiterpenes, flavonoids, lignans, and essential oils. Extracts from different plant parts of Litsea such as bark, leaf, and root show significant pharmacological activities including anticancer, anti-inflammatory, antimicrobial, antioxidant, antidiabetic, anti-HIV, and insecticidal (Wang \& Liu, 2010; Wang et al., 2016; Kamle et al., 2019).

This article is the first review paper that gathers the relevant literature to congregate the chemical and pharmacological properties of Litsea garciae. The common name of $L$. garciae is bagnolo/wuru lilin. In the Sarawak state of Malaysia, the common name differs according to the local languages: engkala as

\footnotetext{
* To whom correspondence should be addressed.
}

in Malay language, enkala/pedar as in Iban language, and ta'ang as in Bidayuh language (Poli \& Assim, 2019). Litsea garciae originated from Borneo (Sabah and Sarawak in Malaysia, Indonesian Kalimantan, and Brunei), Indonesia (Java and Bangka), Taiwan, and the Philippines. It grows wild from seed and can be found in the inland riparian forest, secondary forest, and rarely in mixed dipterocarp. Litsea garciae is a sub-canopy, broadleaved evergreen tree that maintains its green leaves throughout the year and bears fruit once a year (Figure 1).

The edible part of $L$. garciae fruit includes the fleshy part and the thin peel (Figure 2). It has a flavor that is comparable to the Lauracea, Persea americana (common name, avocado), and has a nickname of "Borneo avocado". The literature search revealed only a few publications on L. garciae. Since there is a lack of findings and information on L. garciae, this literature review aims to reveal what is known so far on its nutritional compositions, medicinal uses, and other applications.

\section{Nutritional compositions of Litsea garciae}

Proximate and mineral compositions of Litsea garciae

The proximate and mineral composition data are obtained from Voon and Kueh (1999) and Husen (2015). There are different results obtained from both studies which are probably due to the different analyses used and sites of plant collection (Demir \& 


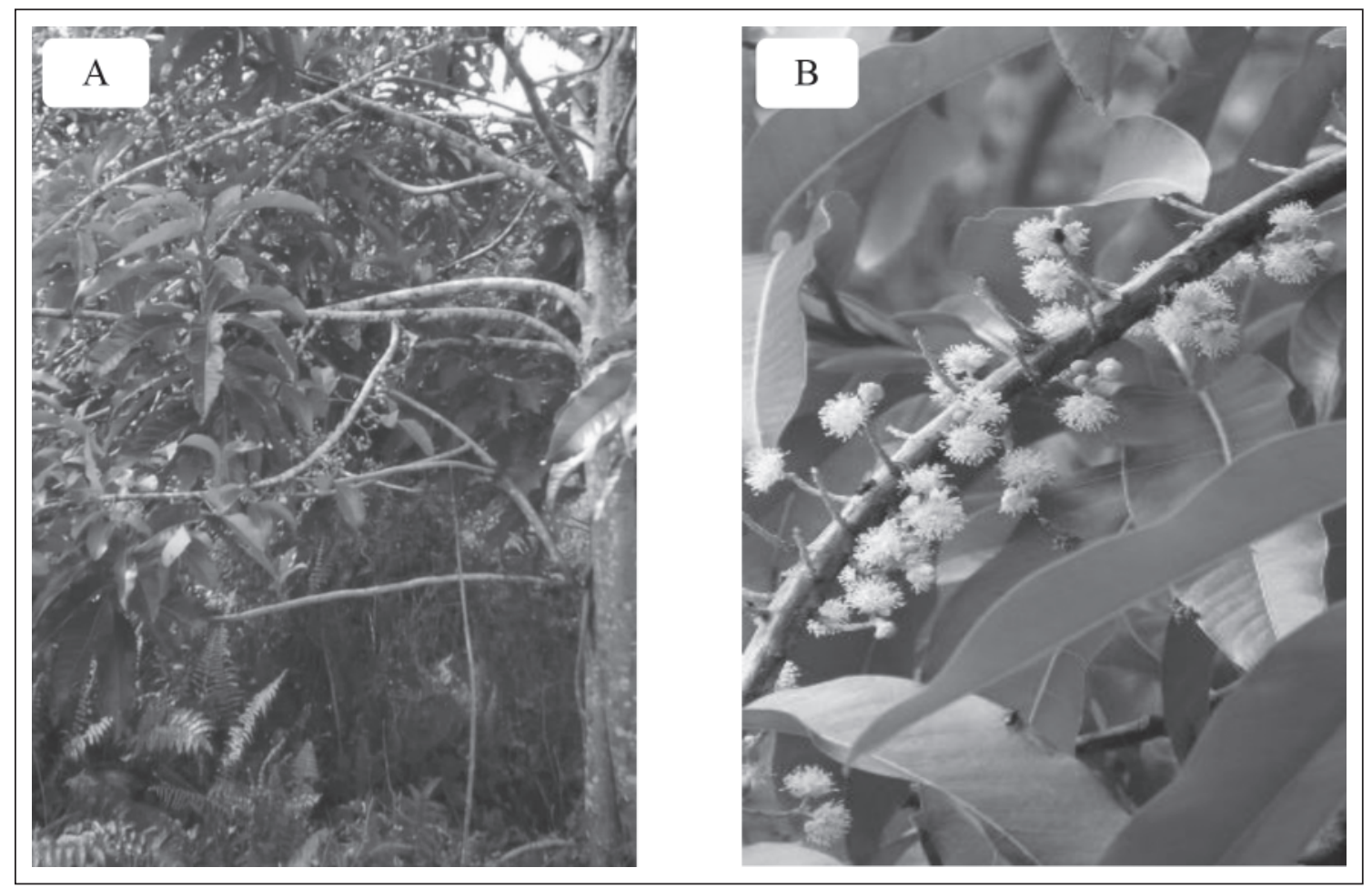

Fig. 1. Litsea garciae bearing fruits (A) and flowers (B) (adapted from (Bukbi, 2019)).

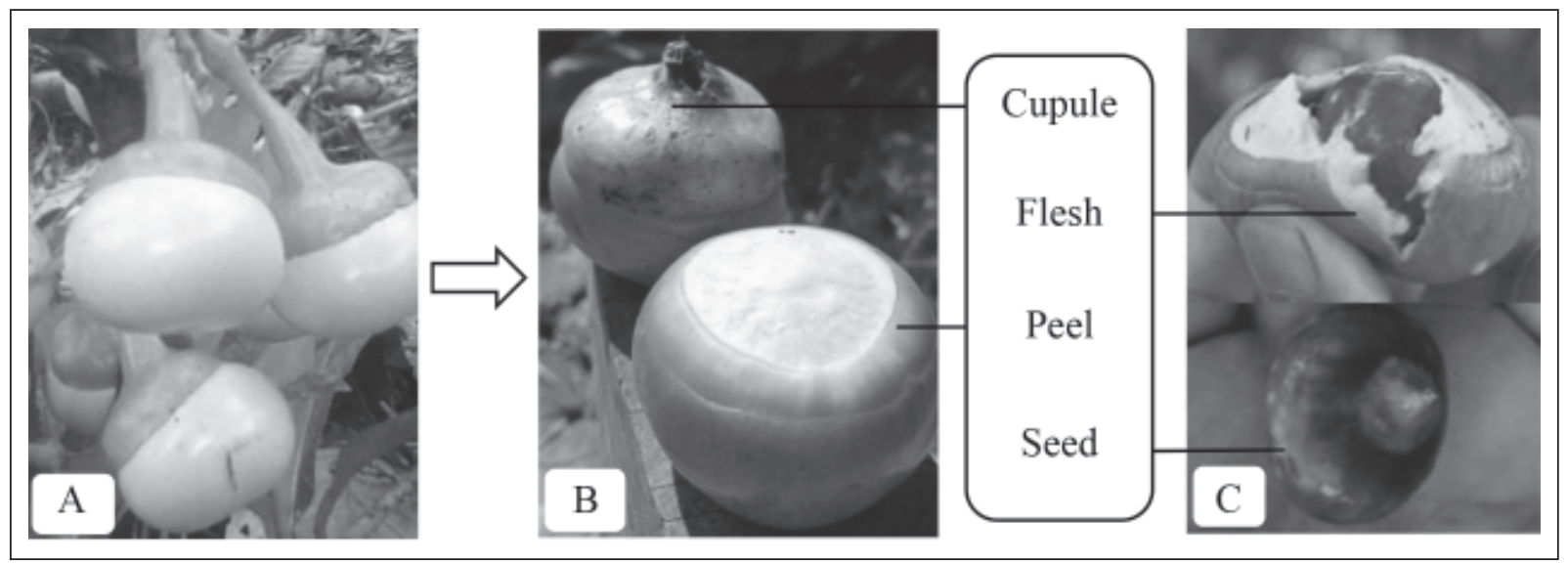

Fig. 2. Transformation of the white, unripe L. garciae fruit (A) into red, ripe fruit (B) with different parts of L. garciae fruit (C) (adapted from (Lim, 2012)).

Ozcan, 2001). Litsea garciae contains a substantial amount of energy with the flesh contains higher energy than the seed (Table 1). The energy content in L. garciae is lower than avocado $(160 \mathrm{kcal})$ and durian (147 kcal) but higher than a banana ( $89 \mathrm{kcal})$ and papaya (43 kcal) (USDA, 2012). Voon and Kueh (1999) report that the flesh has a high moisture content $(78.3 \%)$, which is in agreement with Husen (2015) $(68.8 \%$ in flesh \& $71.7 \%$ in seed). Moisture content is important as it affects the stability and quality of the fruit besides contributing to the refreshing character of the fruit. According to Voon and Kueh (1999), there is a higher percentage of fat
(6.8\%) compared to protein $(1.4 \%)$ in the L. garciae flesh. The fat content gives L. garciae the creamy texture and buttermilk taste. Husen (2015) shows that L. garciae has a high content of carbohydrate $(22.1 \%$ in the flesh and $18.6 \%$ in the seed) which probably account for its high energy content.

The ash content is the measure of the mineral contents present in this fruit. The ash content of the flesh is $2.5 \%$ while the seed has $1.4 \%$. The findings of mineral contents by Voon and Kueh (1999) are lower than by Husen (2015) except for magnesium, copper, and zinc (Table 1). The flesh of L. garciae contains $652.9 \mathrm{mg}$ of potassium and $91.5 \mathrm{mg}$ of 
Table 1. Nutrient contents of the flesh and seed of $L$. garciae fruit per $100 \mathrm{~g}$ of flesh/seed portion

\begin{tabular}{lccc}
\hline Nutrient Contents & Flesh & Flesh & Seed \\
\hline Proximates & & & \\
$\quad$ Energy (kcal) & 104 & 93.3 & 83.4 \\
Moisture (\%) & 78.3 & 68.8 & 71.7 \\
Protein (\%) & 1.4 & 2.5 & 3.3 \\
Fat (\%) & 6.8 & NA & NA \\
Carb (\%) & 10.0 & 22.1 & 18.6 \\
Crude fibre (\%) & 1.0 & 4.0 & 5.0 \\
Ash (\%) & 2.5 & 2.5 & 1.4 \\
& & & \\
Minerals & 26 & NA & NA \\
Phosphorus (mg) & 355 & 652.9 & 331.5 \\
Potassium (mg) & 7 & 7 & 2.4 \\
Calcium (mg) & 17 & 3.7 & 1.8 \\
Magnesium & 0.5 & 4.9 & 1.1 \\
Iron & 5 & NA & NA \\
Manganese (p.p.m) & 2.6 & 1.0 & 0.6 \\
Copper (p.p.m) & 10.2 & 1.6 & 1.1 \\
Zinc (p.p.m) & NA & 91.5 & 6.3 \\
Sodium & 3.4 & 11.8 (FD) & 4.8 (FD) \\
Vitamin C & & 34.7 (SHSD) & 13 (SHSD) \\
& Voon \& Kueh (1999) & Husen (2015) & Husen (2015) \\
Authors & & & \\
\hline
\end{tabular}

$\mathrm{NA}=$ Not available; FD = freeze dried; SHSD = superheated-stream dried.

sodium per $100 \mathrm{~g}$ of flesh part where both values are higher than the non-edible seed (Husen, 2015). Potassium and sodium are electrolytes that regulate the body fluid and blood volume. Adequate potassium and sodium intake may promote blood pressure control in adults. The United States Food and Drug Administration (FDA) (FDA, 2000) claims that food containing $350 \mathrm{mg}$ of potassium and less than $140 \mathrm{mg}$ of sodium has the medical benefit for blood pressure; thus, this suggests that L. garciae is healthy food to consume.

Husen (2015) reports a high content of vitamin $\mathrm{C}$ in the L. garciae flesh. Vitamin C is necessary for the growth, development, and repair of all body tissues in addition to its antioxidant properties. The vitamin $\mathrm{C}$ content of the flesh is $11.8 \mathrm{mg}$ and $34.7 \mathrm{mg}$ by using the freeze-drying (FD) method and superheated-steam drying (SHSD) method respectively. In the SHSD method, the time taken for the flesh to reach the final moisture of about $10 \%$ is three hours compared to several days when using the FD method. Hence, there is a possibility that the vitamin $\mathrm{C}$ content is affected during the lengthy time of drying the flesh samples. The vitamin content of L. garciae is similar to mango $(36.4 \mathrm{mg} / 100 \mathrm{~g})$ and higher than Persea americana flesh $(8.0 \mathrm{mg} / 100 \mathrm{~g})$ (Dreher \& Davenport, 2013).

\section{Fatty acid composition}

There is a slight variation in the fatty acid compositions of L. garciae seed oils extracted from different districts in Sarawak, Malaysia (Poli \&
Assim, 2019). This is probably contributed by the environmental factors and growth conditions among the different districts (Sanchez-Martin et al., 2018). The seed oil of L. garciae is very rich in saturated fatty acids (SFA) $(76.94 \pm 1.50 \%)$, contains a moderate percentage of monounsaturated fatty acids (MUFA) $(16.23 \pm 1.20 \%)$, and a small percentage of polyunsaturated fatty acids (PUFA) $(7.1 \pm 0.79 \%)$ (Poli \& Assim, 2019). The predominant component of SFA in L. garciae seed oil is lauric acid (40.73 \pm $2.81 \%)$, followed by myristic acid (19.69 $\pm 0.52 \%)$, palmitic acid $(7.2 \pm 0.63 \%)$, and capric acid $(6.07 \pm$ $2.01 \%$ ). The significant amount of MUFA and PUFA of $L$. garciae seed oil are contributed by oleic acid $(14.98 \pm 1.44 \%)$ and linoleic acid $(7.10 \pm 0.79 \%)$ respectively. Litsea garciae has a comparable amount of beneficial SFAs to coconut oil and palm oil (Poli \& Assim, 2019), and it has more unsaturated fatty acids than coconut oil which suggests that it can be used as an alternative for coconut oil and palm oil. Currently, available data on the composition of fatty acid of $L$. garciae are only for the seed oil. It would be interesting to know the compositions of fatty acid from the flesh part of $L$. garciae too since this is the edible part of the plant.

Nevertheless, the $P$. americana kernel oil is loaded with good fat. It possesses a low proportion of SFA $(32.50 \pm 0.12 \%)$, with a predominance of palmitic acid at $20.85 \pm 0.84 \%$. There is a high proportion of unsaturated fatty acids accounting for approximately $67 \%$ of the total fatty acids. The MUFA content is $20.71 \pm 0.14 \%$, with a predominance 
Table 2. Comparison of fatty acid composition between L. garciae, P. americana, C. nucifera, and E. guineensis kernel oils

\begin{tabular}{|c|c|c|c|c|c|}
\hline \multirow{2}{*}{\multicolumn{2}{|c|}{ Fatty acids }} & \multicolumn{4}{|c|}{$\%$ of fatty acids } \\
\hline & & \multirow{2}{*}{$\begin{array}{c}\text { Engkala } \\
(\text { L. garciae) } \\
\text { (Poli \& Assim, } \\
\text { 2019) } \\
-\end{array}$} & \multirow{2}{*}{$\begin{array}{c}\text { Avocado } \\
(P . \text { americana } \\
\text { Mill) (Bora } \\
\text { et al., 2001) }\end{array}$} & \multirow{2}{*}{$\begin{array}{c}\text { Coconut } \\
\text { (C. nucifera) } \\
\text { (Chowdhury } \\
\text { et al., 2007) } \\
-\end{array}$} & \multirow{2}{*}{$\begin{array}{c}\text { Palm } \\
\text { (E. guineensis } \\
\text { (Chowdhury } \\
\text { et al., 2007) } \\
-\end{array}$} \\
\hline $\mathrm{C} 6: 0$ & Caproic acid & & & & \\
\hline $\mathrm{C} 7: 0$ & Enanthic acid & - & $0.29 \pm 0.10$ & - & - \\
\hline C8:0 & Caprylic acid & - & $0.28 \pm 0.05$ & $6.21 \pm 0.34$ & - \\
\hline $\mathrm{Cg}: 0$ & Pelargonic acid & - & $0.22 \pm 0.01$ & - & - \\
\hline C10:0 & Capric acid & $6.07 \pm 2.01$ & - & $6.15 \pm 0.21$ & - \\
\hline C11:0 & Undecylic acid & $0.64 \pm 0.02$ & - & - & - \\
\hline C12:0 & Lauric acid & $40.73 \pm 2.81$ & $0.28 \pm 0.05$ & $51.02 \pm 0.71$ & - \\
\hline C13:0 & Tridecylic acid & $0.58 \pm 0.10$ & $0.17 \pm 0.01$ & - & - \\
\hline C14:0 & Myristic acid & $19.69 \pm 0.52$ & $0.54 \pm 0.05$ & $18.94 \pm 0.63$ & $1.23 \pm 0.28$ \\
\hline C15:0 & - & - & $2.33 \pm 0.11$ & - & - \\
\hline C16:0 & Palmitic acid & $7.23 \pm 0.63$ & $20.85 \pm 0.84$ & $8.62 \pm 0.50$ & $41.78 \pm 1.27$ \\
\hline C18:0 & Stearic acid & $2.01 \pm 1.48$ & $1.73 \pm 0.02$ & $1.94 \pm 0.17$ & $3.39 \pm 0.65$ \\
\hline C19:0 & Nonadecylic acid & - & $1.19 \pm 0.01$ & - & - \\
\hline $\mathrm{C} 20: 0$ & Arachidic acid & - & $0.61 \pm 0.34$ & - & - \\
\hline $\mathrm{C} 22: 0$ & Behenic acid & - & $0.04 \pm 0.02$ & - & - \\
\hline $\mathrm{C} 24: 0$ & Lignoceric acid & - & $1.11 \pm 0.02$ & - & - \\
\hline Total SFA & & $76.94 \pm 1.50$ & $32.50 \pm 0.12$ & $92.92 \pm 0.56$ & $46.34 \pm 0.40$ \\
\hline $\mathrm{C} 14: 1$ & Myristoleic acid & - & $0.25 \pm 0.00$ & - & - \\
\hline C15:1 & - & - & $0.32 \pm 0.16$ & - & - \\
\hline C16:1 & Palmitoleic acid & $0.63 \pm 0.02$ & $1.79 \pm 0.33$ & - & - \\
\hline C17:1 & - & - & $0.37 \pm 0.08$ & - & - \\
\hline C18:1 & Oleic acid & $14.98 \pm 1.44$ & $17.41 \pm 0.06$ & $5.84 \pm 0.50$ & $41.90 \pm 1.20$ \\
\hline C20:1 & Gondoic acid & $0.62 \pm 0.01$ & $0.45 \pm 0.28$ & - & - \\
\hline $\mathrm{C} 22: 1$ & Erucic acid & - & $0.12 \pm 0.04$ & - & - \\
\hline Total MUFA ${ }^{\mathrm{b}}$ & & $16.23 \pm 1.20$ & $20.71 \pm 0.14$ & $5.84 \pm 0.46$ & $41.46 \pm 0.56$ \\
\hline C18:2 & Linoleic acid & $7.10 \pm 0.79$ & $38.89 \pm 0.59$ & $1.28 \pm 0.18$ & $11.03 \pm 0.02$ \\
\hline C18:3 & $\alpha$-Linolenic acid & - & $6.58 \pm 0.03$ & - & - \\
\hline $\mathrm{C} 20: 3$ & - & - & $1.26 \pm 0.03$ & - & - \\
\hline Total PUFA ${ }^{c}$ & & $7.10 \pm 0.79$ & $46.73 \pm 0.22$ & $1.28 \pm 0.17$ & $11.84 \pm 0.92$ \\
\hline
\end{tabular}

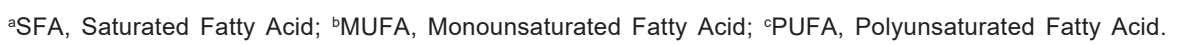

of oleic acid at $17.41 \pm 0.06 \%$. The PUFA content is $46.73 \pm 0.22 \%$, with a predominance of linoleic acid at $38.89 \pm 0.59 \%$ (Dubois et al., 2007). Estruch et al. (2013) show that a diet supplemented with foods rich in unsaturated fatty acids reduces the incidence of cardiovascular events by $30 \%$ after a follow-up of about 5 years in subjects at high risk for cardiovascular disease.

\section{Phytochemicals}

There are about 63 alkaloid compounds that have been identified in the genus Litsea (Kamle et al., 2019). A study by Lee et al. (1995) obtained a few alkaloids from L. garciae which are actinodaphnine, boldine, isodomesticine, laurolitsine, and reticuline. Then, Wulandari et al. (2018) showed that all the extracts from branch, bark, and leaf of L. garciae, formed using hexane, ethyl acetate, and ethanol contain alkaloid and carotenoids (Table 3). Coumarin is only absent in the ethyl acetate leaf extract but present in all of the other extracts, while triterpenoid and steroid are absent in n-hexane extract and ethanol extract respectively. Saponins are absent in all of the extracts from the three solvents. Saponins are glycosides of triterpenes and steroids (Mugford \& Osbourn, 2012). The absence of saponins in this study is probably because triterpenes and steroids are not detected together in all of the samples (Table 3 ), hence no formation of saponin in the plants. These results can also indicate that the different solvents due to the differences in polarity will selectively extract different compounds. The 
Table 3. Phytochemical screening of L. garciae (adapted from Wulandari et al., 2018)

\begin{tabular}{|c|c|c|c|c|c|c|c|c|c|c|}
\hline Solvent & Part & Alk & Flav & Sap & Tan & Triter & Ste & Car & Cou & Caro \\
\hline \multirow{3}{*}{$n$-hexane } & Branch & + & - & - & + & - & - & + & + & - \\
\hline & Bark & + & + & - & - & - & + & + & + & - \\
\hline & Leaf & + & + & - & + & - & - & + & + & - \\
\hline \multirow{3}{*}{ Ethyl acetate } & Branch & + & + & - & + & + & - & + & + & - \\
\hline & Bark & + & - & - & - & + & - & + & + & + \\
\hline & Leaf & + & - & - & + & - & + & + & - & + \\
\hline \multirow{3}{*}{ Ethanol } & Branch & + & + & - & + & + & - & + & + & - \\
\hline & Bark & + & + & - & + & + & - & + & + & + \\
\hline & Leaf & + & + & - & - & + & - & + & + & - \\
\hline
\end{tabular}

Remarks: (+) Present, (-) Absent, Alk; Alkaloids, Flav; Flavonoids, Sap; Saponins, Tan; Tannins, Triter; Triterpenoid, Ste; Steroid, Car; Carbohydrate, Cou; Coumarin, Caro; Carotenoids.

phytochemicals that are detected in L. garciae are also present in the other Litsea species, and they are shown to have antioxidant, antiplatelet, antitumour, anticonvulsant, antibacterial, antiviral, and antiplasmodial effects (Othman et al., 2019; Kamle et al., 2019).

\section{Phenolic and flavonoid content}

Plant parts and fruits have been shown by many epidemiological studies to be great sources of natural antioxidants. Phenolic compounds are abundant structures in plants, and antioxidant compounds are usually in the phenolic form. Phenol compounds can destroy radicals because they contain hydroxyl groups. The hydrogen atom from the hydroxyl groups is abstracted by the hydroxyl radical resulting in phenol being converted to stable phenoxyl radicals. Therefore, the determination of the quantity of phenolic compounds is very important to ascertain the antioxidant capacity of plant extracts (Aksoy et al., 2013). The most important single group of phenolics in food are flavonoids which consist mainly of catechins, proanthocyanins, anthocyanidins, flavones, flavonols, and their glycosides (Tungmunnithum et al., 2018). Flavonoids are crucial antioxidants since they have redox potential, which allows them to act as a reducing agent, hydrogen donors, and singlet oxygen quenchers (Panche et al., 2016). The presence of flavonoids is an indication that the plant could have anti-inflammatory, anti-allergic, and antithrombotic or vasoprotective effects (Panche et al., 2016).

A study by Wulandari et al. (2018) shows that all the plant parts of $L$. garciae contain a significant level of total phenolic, total flavonoid, and total anthocyanin. The ethanol extract has the highest total phenolic and flavonoid contents in all the plant parts as compared to n-hexane and ethyl acetate extracts. This can suggest that ethanol is the solvent of choice for total phenolic and flavonoid extraction (Table 4). About 39 compounds of flavonoids have been recognized in Litsea species which are primarily flavones, flavanols, flavanones, flavanonols, anthocyanidins, chalcones, and flavan3-ols (Wang et al., 2016). Both flavonoid and phenolic compounds are known to have multiple biological effects including antioxidant and antiinflammatory properties.

For the fruit part (Table 5), the total phenolic content is highest in the cupule and seed, followed by the flesh from both the $80 \%$ methanol and aqueous extracts. The same trend is also observed for flavonoid contents where flavonoid content is highest in the cupule and seed followed by the flesh from both $80 \%$ methanol and aqueous extracts. On the other hand, the flesh recorded the highest content of anthocyanin, followed by the seed and then cupule for both the $80 \%$ methanol and aqueous extracts. Anthocyanin is naturally occurring pigments in fruits and vegetables belonging to the group of flavonoids. There are a few studies regarding the positive association of their intake with healthy biological effects such as reducing the risk of coronary heart disease, acting as antioxidants, improving visual acuity, and having anticancer properties (Mukherjee, 2019).

\section{Pharmacological properties of Litsea garciae}

\section{Traditional use of L. garciae}

In Borneo, the indigenous people use some parts of the L. garciae plants such as the leaves and barks for traditional medicinal uses. In Sarawak, the Ibans use the ground bark of L. garciae as a dressing for the treatment of caterpillar stings and boils (Mirfat et al., 2018). The bark is also used to make a decoction for the treatment of rectal bleeding. The Selako people use a poultice of leaves and young shoots of $L$. garciae with the combination of shallot and fennel seeds for the treatment of skin infections, diseases, and burns. The Kayan people treat beriberi by applying a warm poultice of $L$. garciae leaves, 
Table 4. Total phenolic and flavonoid content of L. garciae (adapted from Wulandari et al., 2018)

\begin{tabular}{llcc}
\hline Solvent & Part & Phenolic $(\mu \mathrm{g} \mathrm{GAE} / \mathrm{mg}$ extract $)$ & Flavonoid $(\mu \mathrm{g}$ GAE/mg extract) \\
\hline \multirow{3}{*}{$n$-hexane } & Branch & $30 \pm 0.002$ & $190 \pm 0.004$ \\
& Bark & $40 \pm 0.002$ & $170 \pm 0.003$ \\
& Leaf & $30 \pm 0.001$ & $110 \pm 0.002$ \\
\hline \multirow{3}{*}{ Ethyl acetate } & Branch & $30 \pm 0.002$ & $140 \pm 0.005$ \\
& Bark & $40 \pm 0.004$ & $160 \pm 0.005$ \\
& Leaf & $40 \pm 0.004$ & $210 \pm 0.004$ \\
\hline \multirow{3}{*}{ Ethanol } & Branch & $100 \pm 0.001$ & $1010 \pm 0.002$ \\
& Bark & $90 \pm 0.009$ & $800 \pm 0.001$ \\
& Leaf & $100 \pm 0.001$ & $240 \pm 0.001$ \\
\hline
\end{tabular}

Table 5. The total phenolic, flavonoid, and anthocyanin contents of different parts of L. garciae fruit extracts (adapted from Hassan et al., 2013)

\begin{tabular}{lccccccc}
\hline \multirow{2}{*}{ Chemical content } & \multicolumn{3}{c}{$80 \%$ methanol extract } & & \multicolumn{3}{c}{ Aqueous extract } \\
\cline { 2 - 3 } & Cupule & Seed & Flesh & & Cupule & Seed & Flesh \\
\hline Total phenolic (mg GAE/g) & $8.29 \pm 0.70$ & $8.09 \pm 0.60$ & $2.65 \pm 0.11$ & & $3.71 \pm 0.24$ & $3.54 \pm 0.17$ & $2.01 \pm 0.07$ \\
Total flavonoid (mg RE/g) & $6.90 \pm 0.61$ & $5.73 \pm 1.39$ & $2.05 \pm 0.21$ & & $2.88 \pm 0.23$ & $2.63 \pm 0.29$ & $1.46 \pm 0.15$ \\
Total anthocyanin (mg CE/100g) & $0.35 \pm 0.00$ & $2.11 \pm 0.03$ & $4.12 \pm 0.10$ & & $0.22 \pm 0.03$ & $1.42 \pm 0.10$ & $2.83 \pm 0.23$ \\
\hline
\end{tabular}

Table 6. The antioxidant properties of $L$. garciae fruit extracts from different parts using three different assays (adapted from Hassan et al., 2013)

\begin{tabular}{lccccccc}
\hline \multirow{2}{*}{ Assays } & \multicolumn{3}{c}{$80 \%$ methanol extract } & & \multicolumn{3}{c}{ Aqueous extract } \\
\cline { 2 - 3 } & Cupule & Seed & Flesh & & Cupule & Seed & Flesh \\
\hline 1DPPH assay & $16.7 \pm 0.6$ & $17.3 \pm 2.3$ & $60.0 \pm 3.5$ & & $20.0 \pm 0.0$ & $22.7 \pm 2.3$ & $62.7 \pm 4.6$ \\
2FRAP assay & $2,050.0 \pm 28.5$ & $1,910.0 \pm 59.2$ & $410.0 \pm 54.1$ & & $1,650.0 \pm 29.7$ & $690.0 \pm 17.0$ & $210.0 \pm 9.7$ \\
3ABTS assay & $25.05 \pm 1.7$ & $19.14 \pm 1.7$ & $4.05 \pm 0.1$ & & $16.47 \pm 2.0$ & $6.86 \pm 0.6$ & $2.14 \pm 1.0$ \\
\hline
\end{tabular}

1. 2,2-Diphenyl-1-picryl-hydrazyl-hydrate assay (DPPH assay)

$\mathrm{DPPH}$ free radical scavenging activity was expressed as $\mathrm{IC}_{50}(\mathrm{mg} / \mathrm{mL})$.

2. Ferric reducing/antioxidant power (FRAP assay)

FRAP has expressed as $\mu \mathrm{M}$ ferric reduction to ferrous in $1 \mathrm{~g}$ of dry sample. 3)2,2'-3. Azino-bis (3-ethylbenzothiazoline-6-sulphonic acid)

3. 2,2'-Azino-bis (3-ethylbenzothiazoline-6-sulfonic acid

ABTS assay free radical scavenging activity was expressed as $\mathrm{mg}$ ascorbic acid equivalent antioxidant capacity (AEAC) in $1 \mathrm{~g}$ of dry sample.

4. Values are presented as mean $\pm \operatorname{SD}(n=3)$ which, with different letters (within the column), are significantly different at $\alpha=0.05$.

while the Kelabits make a cataplasm using the root bark to cure the sprains. In addition to that, the Penans use the pounded and warmed bark for the treatment of muscular aches and sprains, and the combination of $L$. garciae and durian bark is used as an antidote for snake bites (Lim, 2012).

Besides medicinal purposes, the extraction of oil from the L. garciae seeds is used in the manufacturing of candles and soaps. Litsea garciae woods have also been used as timbers in the construction field (Lim, 2012). It is also suitable for plywood production and interior decoration such as flooring materials, furniture, and paneling.

\section{Antioxidants}

Hassan et al. (2013) demonstrated the potent antioxidant activity of methanol and aqueous extracts of L. garciae using three different assay systems (DPPH assay, FRAP assay, and ABTS assay) (Table 6). The FRAP and ABTS assays show that the non-edible part of $L$. garciae displays the highest antioxidant activity in comparison to the edible part for both the methanol and aqueous extracts in the order of cupule $>$ seed $>$ flesh (Hassan et al., 2013). This is in agreement with the DPPH assay where the lower the $\mathrm{IC}_{50}$, which is the concentration to deplete the DPPH, the better the antioxidant activity 
displayed by the substance. The $\mathrm{IC}_{50}$ values are in the order of cupule $<$ seed $<$ flesh. A previous study by Soong and Barlow (2004) also showed that the total antioxidant activity of the seeds from avocado, jackfruit, longan, mango, and tamarind are also higher compared to the edible portions.

The scavenging activity of $L$. garciae fruit parts shows a similar trend as portrayed by the total phenolic and total flavonoid contents (Table 5) where the cupule has the highest level of total phenolic and flavonoid contents followed by the seed and the flesh. In addition, the detection of alkaloids, flavonoids, tannins, coumarin, and carotenoids (Table 3) in L. garciae suggests that L. garciae is a rich source of natural antioxidants and therefore of potential therapeutic agents in preventing oxidativestress related diseases.

\section{Antimicrobial and antifungal properties}

The branch, bark, and leaf from n-hexane, ethyl acetate, and ethanol solvent extracts of $L$. garciae with concentrations of 1250,625 , and 312.5 p.p.m were tested for their antibacterial activity against Propionibacterium acnes using micro broth dilution test (Wulandari et al., 2018). All the samples inhibit bacterial growth. The n-hexane and ethanol extracts of the branch and ethyl acetate extract of the leaf have a minimum inhibitory concentration (MIC) at 312.5 p.p.m (Table 7). The study of Wulandari et al. (2018) did not show a strong antibacterial activity probably because it used a higher concentration of L. garciae (312.5 to 1250 p.p.m), and besides, the active compound(s) may be present in insufficient quantities to show activity with the dose employed.

The crude extract of $L$. garciae leaf show some antifungal activities (Table 8) (Johnny et al., 2010; Johnny et al., 2011). The methanol extract exhibits higher antifungal activities against $C$. capsici than towards C. gloeosporioides. On the other hand, the chloroform extract shows a higher percentage of radial growth inhibition on $C$. gloeosporioides than towards $C$. capsici. The acetone extracts show approximately a similar percentage of inhibition on C. gloeosporioides and C. capsici at concentrations of 1.00 and $10.00 \mu \mathrm{g} / \mathrm{mL}$ respectively.

The Litsea species have demonstrated antimicrobial and antifungal activities against numerous pathogenic strains. The essential oil of Litsea species has been extensively studied for its antimicrobial activities. For example, essential oil from $L$. cubeba has marked antimicrobial effects on Vibrio parahaemolyticus, Listeria monocytogenes, Lactobacillus plantarum, and Hansenula anomala in vitro, and in food products (Liu \& Yang, 2012). Staphylococcus aureus, Listeria monocytogenes, Escherichia coli, Pseudomonas aeruginosa, Candida albicans, and Aspergillus niger are also sensitive to the cytotoxic activity of the L. cubeba essential oils (Saikia et al., 2013). The presence of aldehydes (Li et al., 2014) and alkaloids (Zhang et al., 2012) in the essential oil probably accounts for its antimicrobial effects. The methanol extract of L. glutinosa exhibits antibacterial activity comparable to chloramphenicol (Mandal et al., 2000) while the essential oil of L. laevigata (Muhammed et al., 2008) and L. acuminata (Su \& Ho, 2013) have great activity against gram-positive bacteria and fungus. The essential oil from the root of $L$. resinosa

Table 7. Minimal Inhibitory Concentration (MIC) of $L$. garciae using antibacterial assay (adapted from Wulandari et al., 2018)

\begin{tabular}{lcc}
\hline Solvent & Part & MIC (p.p.m) \\
\hline \multirow{3}{*}{$n$-hexane } & Branch & 625 \\
& Bark & 312.5 \\
& Leaf & 625 \\
\hline \multirow{2}{*}{ Ethyl acetate } & Branch & 625 \\
& Bark & 1250 \\
& Leaf & 312.5 \\
Ethanol & Branch & 625 \\
& Bark & 312.5 \\
& Leaf & 625 \\
\hline
\end{tabular}

Table 8. The percentage reduction of radial growth $(\mathrm{mm})$ of Colletotrichum gloeosporioides (Cg) and Colletotrichum capsici (Cc) by varying concentrations of $L$. garciae leaf extracts in different solvents using antifungal assay (adapted from Johnny et al., 2010 and Johnny et al., 2011)

\begin{tabular}{lcccc}
\hline \multirow{2}{*}{ Solvent } & \multicolumn{5}{c}{ Mean \pm S.E of \% of Inhibition of Radial Growth (mm) } \\
\cline { 2 - 5 } Methanol & $0.01 \mu \mathrm{g} / \mathrm{mL}$ & $0.10 \mu \mathrm{g} / \mathrm{mL}$ & $1.00 \mu \mathrm{g} / \mathrm{mL}$ & $10.00 \mu \mathrm{g} / \mathrm{mL}$ \\
& $13.31 \pm 0.49$ & $15.17 \pm 0.55$ & $15.26 \pm 0.58$ & $17.22 \pm 0.78$ \\
& $13.59 \pm 0.59$ & $31.08 \pm 0.77$ & $33.77 \pm 0.78$ & $36.71 \pm 1.41$ \\
\hline Chloroform & $14.24 \pm 0.51$ & $15.74 \pm 0.67$ & $17.73 \pm 0.78$ & $19.38 \pm 0.48$ \\
& $1.94 \pm 1.70$ & $5.84 \pm 1.26$ & $8.85 \pm 1.99$ & $9.68 \pm 1.53$ \\
\hline Acetone & $18.88 \pm 0.69$ & $21.16 \pm 0.50$ & $21.78 \pm 0.63$ & $22.68 \pm 0.56$ \\
& $\mathrm{~N}$ & $\mathrm{~N}$ & $24.48 \pm 1.38$ & $25.48 \pm 1.26$ \\
\hline
\end{tabular}

All the values represented the mean \pm standard error. $\mathrm{NI}=$ no inhibition . 
and L. elliptica shows significant antifungal activities with inhibition rates of $80.11 \%$ and $66.85 \%$ respectively (Wong et al., 2014). Thus, the essential oil of $L$. garciae can be explored further for its potential as a natural antimicrobial source.

\section{Anticancer activities}

The anticancer activity of $L$. garciae on human cell lines was investigated using MTT (3-(4,5Dimethylthiazol-2-yl)-2,5-diphenyltetrazolium) method. Litsea garciae has moderate cytotoxic activities against three types of cell lines (Table 9) (Kutoi et al., 2012). The methanolic bark extract of L. garciae has moderate cytotoxic activities against human breast cancer (MCF-7) cell lines and human colorectal cancer (HT-29) cell lines with the $\mathrm{IC}_{50}$ values of 66 and $77 \mu \mathrm{g} / \mathrm{mL}$ respectively, and weak cytotoxic activity against cervical cancer (HeLa) cell lines with $\mathrm{IC}_{50}$ value of $117 \mu \mathrm{g} / \mathrm{mL}$. On the other hand, the methanolic leaf extract has no activity against HeLa cell lines, weak towards MCF-7 cell lines $\left(\mathrm{IC}_{50}=104 \mu \mathrm{g} / \mathrm{mL}\right)$, and has moderate cytotoxicity against HT-29 cell lines $\left(\mathrm{IC}_{50}=73 \mu \mathrm{g} / \mathrm{mL}\right)$.

Other species of Litsea also demonstrate high anticancer activities against numerous cell lines. Among the studies, the alkaloids isolated from the bark of $L$. cubeba exhibit very potent cytotoxic effect on several cancer cell lines such as BGC-823 cells (human gastric carcinoma), HepG2 cells (human hepatocellular carcinoma), MCF-7 cells (human breast cancer), SGC-7901 cells (human gastric adenocarcinoma), SK-MEL-2 (human skin cancer), and SK-OV-3 (ovarian cancer) with $\mathrm{IC}_{50}$ values ranging from 9.54-12.22 $\mu \mathrm{M}$ (Zhang et al., 2012). In addition, the butenolide isolated from the leaves of Litsea lii var. nunkao tahangensis have high cytotoxicity against MCF 7, NCI H460 (non-small lung cancer), and SF 268 (glioblastoma cells) lines in vitro (Wang et al., 2008). Two novel flavonoids with chalcone skeleton isolated from the stem barks of Litsea rubescens and Litsea pedunculata have cytotoxic activities against myeloid leukemia (HL-60) and carcinoma (A431) cell lines and more active than cisplatin (DDP) (Li et al., 2011). The alkaloids, such as boldine, are cytotoxic and induce apoptosis in breast cancer cells (Pydar et al., 2014) as shown by an increase in the release of lactate dehydrogenase, membrane permeability, and DNA fragmentation. Thus, more studies should be carried out to explore the potential of different parts of L. garciae as an anticancer agent.

\section{Anti-inflammatory activity}

Different parts of $L$. garciae have been used in folk medicine for treatments of muscular aches, sprained ankles and knees, skin disease, rectal bleeding, boil, and snakebite, and caterpillar stings
Table 9. Inhibitory concentration of barks and leaves methanolic extract on HeLa, MCF-7, and HT-29 (adapted from Kutoi et al., 2012)

\begin{tabular}{lccc}
\hline \multirow{2}{*}{ Part } & \multicolumn{3}{c}{$\begin{array}{r}\text { Cytotoxicity activities against } \\
\text { cell lines, } I C_{50}\end{array}$} \\
\cline { 2 - 4 } & HeLa & MCF-7 & $H T-29$ \\
\hline Barks $(\mu \mathrm{g} / \mathrm{mL})$ & 117 & 66 & 77 \\
Leaves $(\mu \mathrm{g} / \mathrm{mL})$ & N/A & 104 & 73 \\
\hline
\end{tabular}

Table 10. Lipoxygenase (LO), Hyaluronidase (HO), and Xanthine Oxidase (XO) inhibitory activities (adapted from Kutoi et al., 2012)

\begin{tabular}{lccc}
\hline \multirow{2}{*}{ Part } & \multicolumn{3}{c}{ Anti-Inflammatory Assay (\% of inhibition) } \\
\cline { 2 - 4 } & LO Assay & HO Assay & XO Assay \\
\hline Barks & 1.20 & 11.30 & 2.19 \\
Leaves & 3.85 & 9.51 & 2.26 \\
Fruits & 9.42 & 27.70 & Not Active \\
\hline
\end{tabular}

(Mirfat et al., 2018). To date, only one study was done to show the anti-inflammatory activity of L. garciae. A study by Kutoi et al. (2012) shows the methanolic crude extracts of barks, leaves, and fruits of L. garciae exhibit some anti-inflammatory properties (Table 10). The bark, leaf, and fruit extracts inhibit lipoxygenase activity by $1.20 \%, 3.85 \%$, and $9.42 \%$ respectively. There is a slightly higher inhibition of hyaluronidase activity with inhibition of $11.3 \%, 9.51 \%$, and $27.7 \%$ for the barks, leaves, and fruits respectively. In addition, the bark and leaf extracts inhibit xanthine oxidase activity by $2.19 \%$ and $2.26 \%$ respectively.

Other species of Litsea have been assessed for their anti-inflammatory effects, for example, the methanol extract of $L$. cubeba inhibits nitric oxide (NO) and prostaglandin E2 (PGE2) production in lipopolysaccharide (LPS)-RAW-264.7 macrophages (Choi \& Hwang, 2004). The ethanol and water root extracts of $L$. cubeba can reduce adjuvant arthritis and decrease the expression levels of cyclooxygenase-2 (COX-2) and 5-lipoxygenase in rats with Freund's complete adjuvant-induced arthritis (Lin et al., 2013). The methanol extracts of L. akoensis have significant anti-inflammatory activity by inhibiting the production of nitric oxide by $81.07 \%$ in LPS-induced macrophage at a dose of $25 \mu \mathrm{g} / \mathrm{ml}$ (Lin et al., 2007). The ethanol and chloroform extracts of $L$. japonica fruit significantly inhibit the production of COX-2/PGE2 and NO/iNOS, and pro-inflammatory cytokines by inhibiting the $\mathrm{NF}-\kappa \mathrm{B}$ and $\mathrm{JNK} / \mathrm{p} 38$ MAPK signaling in LPS-induced macrophages (Koo et al., 2014). 


\section{CONCLUSION}

Litsea garciae has the potential to be promoted as a healthy food since its fruit is rich in nutritional components, and several studies had shown that the plant parts contained some pharmacological activities. However, the electronic data search revealed extremely scarce data on $L$. garciae. More studies should be done to identify the chemical constituents, for example, the types of alkaloids, butenolide, terpenes, flavonoids, amides, lignans, steroids, and fatty acids of $L$. garciae. To unravel the full therapeutic potential of the L. garciae plant, more pharmacological investigations should be performed. So far only antioxidants, antimicrobial, antifungal, anti-inflammatory, and anticancer studies were done for L. garciae, and the studies are far from complete. The use of $L$. garciae bark as an antidote for snakebite and dressing for caterpillar stings and a treatment for boils and other skin diseases as claimed by the locals should be explored. Other pharmacological studies on plant parts of $L$. garciae extracted with different solvent systems should be done, for example, the antinociceptive effects, antidiabetic activity, activity on the cardiovascular system, antidiarrheal activity, aphrodisiac, and hepatoprotective.

The authors are currently investigating the lipid composition of $L$. garciae fruit extracted with two solvent systems, which are petroleum ether and chloroform: methanol (1:2). In addition, the authors are also investigating the wound healing potentials of the L. garciae fruit on the fibroblasts cell line. The results from this study will become important contributions and can fill up the gaps in the knowledge on L. garciae.

\section{ACKNOWLEDGEMENT}

The authors are grateful to Universiti Malaysia Sarawak for financially supporting this work (Tun Zaidi Chair Grant, F05/TZC/1916/2019).

\section{REFERENCES}

Aksoy, L., Kolay, E., Ağılönü, Y., Aslan, Z. \& Karg1oğlu, M. 2013. Free radical scavenging activity, total phenolic content, total antioxidant status, and total oxidant status of endemic Thermopsis turcica. Saudi Journal of Biological Sciences, 20(3): 235-239.

Bora, P.S., Narain, N., Rocha, R.V. \& Paulo, M.Q. 2001. Characterization of the oils from the pulp and seeds of avocado (cultivar: Fuerte) fruits. Grasas y aceites, 52(3-4): 171-174.
Bukbi, S. 2019. Pokok engkalak kebun kamek baruk bebuah [Facebook update]. URL https://www. facebook.com/salbiah.bukbi/photos (accessed 8.16.20)

Choi, E.M. \& Hwang, J.K. 2004. Effects of methanolic extract and fractions from Litsea cubeba bark on the production of inflammatory mediators in RAW 264.7 cells. Fitoterapia, 75: 141-148.

Chowdhury, K., Banu, L.A., Khan, S. \& Latif, A. 2007. Studies on the fatty acid composition of edible oil. Bangladesh Journal of Scientific and Industrial Research, 42(3): 311-316.

Demir, F. \& Özcan, M. 2001. Chemical and technological properties of rose (Rosa canina L.) fruits grown wild in Turkey. Journal of Food Engineering, 47(4): 333-336.

Dreher, M.L. \& Davenport, A.J. 2013. Hass avocado composition and potential health effects. Critical Reviews in Food Science and Nutrition, 53(7): 738-750.

Dubois, V., Breton, S., Linder, M., Fanni, J. \& Parmentier, M. 2007. Fatty acid profiles of 80 vegetable oils with regard to their nutritional potential. European Journal of Lipid Science and Technology, 109(7): 710-732.

Estruch, R., Ros, E., Salas-Salvadó, J., Covas, M.I., Corella, D., Arós, F., Gómez-Gracia, E., RuizGutiérrez, V., Fiol, M., Lapetra, J., LamuelaRaventos, R.M., Serra-Majem, L., Pintó, X., Basora, J., Muñoz, M.A., Sorlí, J.V., Martínez, J.A. \& Martínez-González, M.A. 2013. Primary prevention of cardiovascular disease with a Mediterranean diet. New England Journal of Medicine, 368(14): 1279-1290.

FDA (Food and Drug Administration). 2000. Potassium and the risk of high blood pressure and stroke. URL https://www.fda.gov/food/foodlabeling-nutrition/health-claim-notificationpotassium-containing-foods (accessed 5.2.21).

Hassan, S.H.A., Fry, J.R. \& Bakar, M.F.A. 2013. Antioxidant and phytochemical study on pengolaban (Litsea garciae), an edible underutilized fruit endemic to Borneo. Food Science and Biotechnology, 22(5): 1-7.

Husen, R. 2015. Potential Use of Superheated-steam Treatment in Underutilised Fruit of Engkala (Litsea garciae) and Evaluation of Its Antioxidant Capacity (PhD). Kyushu Institute of Techology, Japan.

Johnny, L., Yusuf, U.K. \& Nulit, R. 2010. The effect of herbal plant extracts on the growth and sporulation of Colletotrichum gloeosporioides. Journal of Applied Biosciences, 34: 2218-2224. 
Johnny, L., Yusuf, U.K. \& Nulit, R. 2011. Antifungal activity of selected plant leaves crude extracts against a pepper anthracnose fungus, Colletotrichum capsici (Sydow) butler and bisby (Ascomycota: Phyllachorales). African Journal of Biotechnology, 10(20): 4157-4165.

Kamle, M., Mahato, D.K., Lee, K.E., Bajpai, V.K., Gajurel, P.R., Gu, K.S. \& Kumar, P. 2019. Ethnopharmacological properties and medicinal uses of Litsea cubeba. Plants, 8(6): 150.

Koo, H.J., Yoon, W.J., Sohn, E.H., Ham, Y.M., Jang, S.A., Kwon, J., Jeong, Y.J., Kwak, J.H., Sohn, E., Park, S.Y., Jang, K.H., Namkoong, S., Han, H.S., Jung, Y.H. \& Kang, S.C. 2014. The analgesic and anti-inflammatory effects of Litsea japonica fruit are mediated via suppression of NF- $\mathrm{KB}$ and JNK/p38 MAPK activation. International Immunopharmacology, 22: 84-97.

Kutoi, C.J., Yen, K.H. \& Seruji, N.M.U. 2012. Pharmacology evaluation of Litsea garciae (Lauraceae), in Proceedings of the Business Engineering and Industrial Applications Colloquium (BEIAC), IEEE, Kuala Lumpur, Malaysia, pp 31-33.

Lee, S.S., Wang, P.H., Chiou, C.M., Chen, I.S. \& Chen, C.H. 1995. Isoquinoline alkaloids from Litsea garciae and Neolitsea villosa. Chinese Pharmaceutical Journal, 47(1): 69-75.

Li, L., Zhao, X.T., Luo, Y.P., Zhao, J.F., Yang, X.D., \& Zhang, H.B. 2011. Novel cytotoxic chalcones from Litsea rubescens and Litsea pedunculata. Bioorganic \& Medicinal Chemistry Letters, 21(24): 7431-7433.

Li, W.R., Shi, Q.S., Liang, Q., Xie, X.B., Huang, X.M. \& Chen, Y.B. 2014. Antibacterial activity and kinetics of Litsea cubeba oil on Escherichia coli. PLoS One, 9(11): e110983.

Lim, T.K. 2012. Litsea garciae. In: Edible Medicinal and Non Medicinal Plants. Springer, Dordrecht. pp. 75-77.

Lin, B., Zhang, H., Zhao, X.X., Rahman, K., Wang, Y., Ma, X.Q., Zheng, C.J., Zhang, Q.Y., Han, T. \& Qin, L.P. 2013. Inhibitory effects of the root extract of Litsea cubeba (Lour.) Pers. on adjuvant arthritis in rats. Journal of Ethnopharmacology, 147: 327-334.

Lin, C.T., Chu, F.H., Tseng, Y.H., Tsai, J.B., Chang, S.T. \& Wang, S.Y. 2007. Bioactivity investigation of Lauraceae trees grown in Taiwan. Pharmaceutical Biology, 45: 638-644.

Liu, T.T. \& Yang, T.S. 2012. Antimicrobial impact of the components of essential oil of Litsea cubeba from Taiwan and antimicrobial activity of the oil in food systems. International Journal of Food Microbiology, 156(1): 68-75.
Mandal, S.C., Kumar, C.K., Majumder, A., Majumder, R. \& Maity, B.C. 2000. Antibacterial activity of Litsea glutinosa bark. Fitoterapia, 71(4): 439-41.

Mehat, S.I. 2008. Chemical Compositions of Essential Oil From Six Litsea species (Bachelor of Science). Universiti Malaysia Sarawak.

Mirfat, A.H.S., Amin, I., Kartinee, K.N., Muhajir, H. \& Shukri, M.A.M. 2018. Underutilised fruits: a review of phytochemistry and biological properties. Journal of Food Bioactives, 1: 2-30.

Mugford, S.T. \& Osbourn, A. 2012. Saponin synthesis and function. In: Isoprenoid synthesis in plants and microorganisms. Springer, New York. pp. 405-42.

Muhammed, A.M., Subbu, R.M., Jirovetz, L. \& Mohamed, S.P. 2008. Composition and antimicrobial analysis of the essential oil of Litsea laevigata nees. (Lauraceae). Natural Product Communications, 3(7): 1069-1072.

Mukherjee, P.K. 2019. Phyto pharmaceuticals, nutraceuticals and their evaluation. In: Quality Control and Evaluation of Herbal Drugs. Elsevier, Amsterdam. pp 707-722.

Othman, L., Sleiman, A. \& Abdel-Massih, R.M. 2019. Antimicrobial activity of polyphenols and alkaloids in middle eastern plants. Frontiers in Microbiology, 10: 911.

Panche, A., Diwan, A. \& Chandra, S. 2016. Flavonoids: An overview. Journal of Nutritional Science, 5: E47.

Paydar, M., Kamalidehghan, B., Wong, Y.L., Wong, W.F., Looi, C.Y. \& Mustafa, M.R. 2014. Evaluation of cytotoxic and chemotherapeutic properties of boldine in breast cancer using in vitro and in vivo models. Drug Design, Development and Therapy, 8: 719-733.

Poli, F.M. \& Assim, Z. 2019. Fatty acid profiles in the kernel oils of Artocarpus odoratissimus and Litsea garciae. Journal of Engineering and Applied Sciences, 14(3): 6135-6138.

Saikia, A.K., Chetia, D., D’Arrigo, M., Smeriglio, A., Strano, T. \& Ruberto, G. 2013. Screening of fruit and leaf essential oils of Litsea cubeba Pers. from north-east India - chemical composition and antimicrobial activity. Journal of Essential Oil Research, 25(4): 330-338.

Sampson, F.B. \& Berry, P.E. 2019. Laurales. URL https://www.britannica.com/plant/Laurales (accessed 8.16.20).

Sánchez-Martín, J., Canales, F.J., Tweed, J., Lee, M., Rubiales, D., Gómez-Cadenas, A., Arbona, V., Mur, L. \& Prats, E. 2018. Fatty acid profile changes during gradual soil water depletion in oats suggests a role for jasmonates in coping with drought. Frontiers in Plant Science, 9: 1077. 
Soong, Y.Y. \& Barlow, P.J. 2004. Antioxidant activity and phenolic content of selected fruit seeds. Food Chemistry, 88(3): 411-417.

Su, Y.C. \& Ho. C.L. 2013. Composition and two activities of the leaf essential oil of Litsea acuminata (Blume) Kurata from Taiwan. Records of Natural Products, 7(1): 27-34.

Tungmunnithum, D., Thongboonyou, A., Pholboon, A. \& Yangsabai, A. 2018. Flavonoids and other phenolic compounds from medicinal plants for pharmaceutical and medical aspects: An overview. Medicines, 5(3): 93.

United States Department of Agriculture (USDA), Agricultural Research Service. 2019. USDA Food Composition Data. URL https://fdc.nal.usda.gov/ $\mathrm{ndb} /$ search/list?home=true. $($ accessed 4.16.21).

Voon, B.H. \& Kueh, H.S. 1999. The nutritional value of indigenous fruits and vegetables in Sarawak. Asia Pacific Journal of Clinical Nutrition, 8(1): 24-31.

Wang, H. \& Liu, Y. 2010. Chemical composition and antibacterial activity of essential oils from different parts of Litsea cubeba. Chemistry \& Biodiversity, 7(1): 229-235.
Wang, T.A., Cheng, M.J., Lee, S.J., Yang, C.W., Chang, H.S. \& Chen, I.S. 2008. Secondary metabolites from the leaves of Litsea lii var. nunkao tahangensis. Helvetica Chimica Acta, 91(6): 1036-1044.

Wang, Y.S., Wen, Z.Q., Li, B.T., Zhang, H.B. \& Yang, J.H. 2016. Ethnobotany, phytochemistry, and pharmacology of the genus Litsea: An update. Journal of Ethnopharmacology, 181: 66-107.

Wong, M.H., Lim, L.F., bin Ahmad, F. \& bin Assim, Z. 2014. Antioxidant and antimicrobial properties of Litsea elliptica Blume and Litsea resinosa Blume (Lauraceae). Asian Pacific Journal of Tropical Biomedicine, 4(5): 386-392.

Wulandari, I., Kusuma, I.W. \& Kuspradini, H. 2018. Antioxidant and antibacterial activity of Litsea garciae. IOP Conference Series: Earth and Environmental Science, 144(1): 012024.

Zhang, W., Hu, J.F., Lv, W.W., Zhao, Q.C. \& Shi, G.B. 2012. Antibacterial, antifungal and cytotoxic isoquinoline alkaloids from Litsea cubeba. Molecules, 17(11): 12950-12960. 
